\title{
Jean-Martin Charcot at the Birth of Russian Neurology
}

\author{
Alla A. Vein \\ Department of Neurology, Leiden University Medical Centre, Leiden, The Netherlands
}

Key Words

Charcot $\cdot$ Russian neurology $\cdot$ History

\begin{abstract}
Russian neurology was virtually nonexistent in the middle of the 19th century which made a traineeship abroad an absolute necessity. Charcot and his school did not just offer professional training, but created the best minds, which would determine the direction of neurology and psychiatry in Russia for many decades. After returning home, young Russian doctors not only implemented everything they had learned in Western Europe, but proceeded to make their own original contributions. The most talented pupils of Charcot, including such prominent names as Kozhevnikov, Korsakov, Minor, Bekhterev and Darkshevich, became the founders of neurological schools in Russia. They laid the basis for the further development of neurology and psychiatry. Remarkably, though trained by the same teachers, each of these future 'founding fathers' of these neurological and psychiatric schools followed his own individual path which resulted in an undeniable diversity in Russian neurology and psychiatry during the period of their formation.
\end{abstract}

Copyright $\odot 2011$ S. Karger AG, Basel

\section{KARGER}

Fax +4161306 1234 E-Mail karger@karger.ch www.karger.com
(C) 2011 S. Karger AG, Basel 0014-3022/11/0652-0075\$38.00/0

\section{Introduction}

Jean-Martin Charcot is considered to be the founder of modern neurology, a title he rightly deserves, not only because of his clinical descriptions and classification of the nervous diseases, but also because it is through his pupils that modern neurology emerged as a discipline. Having himself been a grateful and dedicated pupil, Charcot made teaching one of his main priorities. He devoted every morning at Salpêtrière entirely to teaching and private conferences with the students, reserving Tuesdays and Fridays for his official public lectures [1]. Obviously, the core of his pupils was shaped by his close collaboration with names such as Marie, Babinski, Pitres, Gilles de la Tourette, Marinesco, Janet, Souques, and many others, who designed the way in which French neurology developed over many years. Charcot's main goal was the creation of a Chair of Neurology by the Faculty of Medicine and his accession to the Académie des Sciences et de Médecine. Receiving foreigners and chairing their theses belonged to his approach to achieve his goal and to eliminate any competition from other colleagues in France. Charcot's knowledge, enthusiasm and artistry attracted a huge number of pupils from abroad, and as his

Alla A. Vein, MD, PhD

Department of Neurology, Leiden University Medical Centre

PO Box 9600, NL-2300 RC Leiden (The Netherlands)

Tel. +31715262895 or +31715261637

Fax +31 71524 8253, E-Mail a.a.vein@lumc.nl 
fame grew, so did the number of foreign students. In the first year of his professorship, $10 \%$ of the students were from abroad, while during the last 6 years of his career the proportion rose to $40 \%$. From 1873 to 1893 , Charcot chaired 223 theses, 40 of which were written by foreigners (18\%). Of these, $42 \%$ came from Russia and Eastern European countries $[2,3]$.

Charcot, as well as two other highly recognized representatives of French science and medicine of the time Claude Bernard (1813-1878) and Louis Pasteur (18221895), was very definitely a Russophile [4]. All three of them attracted numerous young doctors and scholars to Paris, with those from Russia accounting for a considerable proportion of Charcot's foreign pupils. In the 19th century, if a Russian medical graduate was seeking a medical faculty position, the degree of Doctor of Medicine was essential; therefore, there was serious competition for additional training in Western Europe. Obviously, the magnetism of prominence in medical science was shared by three countries - Germany, Great Britain and France. While these countries competed against each other, Russian scholars were determined to acquire the best of European experience.

Russians were no strangers to France, or Paris in particular. Historically, culturally and politically, there were many contacts between these two countries. During the 19th century, Russians considered travelling in France to be a form of cultural and intellectual apprenticeship.

In the second part of the 19th century, there was an explosion of interest in the neurosciences in Russia. From being almost nonexistent, the country managed to rival European standards and in some aspects even surpass these, producing such celebrated names as I.M. Sechenov (1829-1905), I.F. Cyon (1843-1911) and I.P. Pavlov (18491936) in a very short period of time. A decisive role in promoting neurophysiological science in Russia belongs to one of the most outstanding personalities in Russian medicine - S.P. Botkin (1832-1889). It was his visit to Paris in 1860 and his work under the auspices of Bernard that formed his new approach to medical sciences. In Bernard's laboratory, Botkin worked on the physiology of digestion and metabolism and the influence of the central nervous system on visceral functions. In his Paris period, he also worked with Armand Trousseau (1801-1867), who was considered to be the best internist in Paris at that time. At the age of 29, in 1861, Botkin became a Professor of Faculty of the Therapeutic Clinic. He was the founder of scientific clinical medicine in Russia. Botkin founded the first experimental and analytical laboratory, where he studied the physiological and pharmacological effects of drugs. He introduced triage, pathological anatomy and postmortem diagnostics into Russian medical practice. Botkin influenced an entire generation of Russian medical doctors and scientists. Among his pupils was Pavlov, who later, in 1904, became the first Russian Nobel Prize winner in Physiology or Medicine [5].

There was a comparable situation in the fields of neurology and psychiatry. Although the course on nervous and mental diseases had been given in Russian for some time (since 1768 at Moscow University), there was an evident need for extra training abroad [6].

\section{Pupils}

One of the most influential personalities in Russian neurology (particularly in Moscow) was A.Ya. Kozhevnikov (1836-1902). After graduating from Moscow University and training in Germany and Great Britain, he worked at Salpêtrière from 1867 to 1868. In Charcot's laboratory, Kozhevnikov convincingly showed that spinal degeneration could be traced to the motor cortex. Charcot commented that many researchers had previously failed to correlate a primary lesion of the gray matter of the medulla with the clinical signs known as glossolabiallaryngeal paralysis [7]. While in Europe, Kozhevnikov visited medical institutions and studied the way they were organized, in particular, the new St. Anne's Psychiatric Clinic in Paris, on which he made a detailed report for Moscow University [8]. The time spent with Charcot strengthened Kozhevnikov's belief that neurology has to be seen as an independent discipline. Remarkably, Kozhevnikov managed to achieve this 13 years earlier than Charcot did in Paris. In 1869, on his return to Russia, the Moscow University Council chose the 33-year-old Kozhevnikov, a lecturer on nervous and mental diseases, to lead the department. Kozhevnikov became the first Russian Professor of Neuropathology (la pathologie nerveuse). This is how he, Charcot's devoted disciple, preferred to call the discipline - a term that would be used in Russia (and later, Soviet Union) for many decades thereafter. It was not until 1882 that Charcot was appointed Chair of the Study of Diseases of the Nervous System [6, 9]. Kozhevnikov was a faithful follower of Charcot's anatomoclinical approach. The Moscow School of Neurology, founded by Kozhevnikov, worked effectively for many decades in the fields of neuroanatomy, neuromorphology and localization of nervous diseases. In the world of neurology, the name of Kozhevnikov is mainly known for his description of Epilepsia corticalis sive partialis continua 
or Kozhevnikov epilepsy from 1894 [10]. Nevertheless, his scientific interests were broad and there is much similarity between research topics of Kozhevnikov and Charcot. Kozhevnikov published papers on amyotrophic lateral sclerosis (Charcot's disease), tabes dorsalis (Charcot's joints), aphasia, etc. Like his Parisian teacher, Kozhevnikov's main method of research consisted of clinical observation at the bedside; the case history included, whenever possible, an extensive postmortem study of pathological findings. Curiously, Charcot's latter passion for hypnosis and hysteria never awakened any interest in Kozhevnikov.

On the whole, the respect for Charcot's work in Russia was exceptionally high, as illustrated by the fact that the first translation of Charcot's monograph, 'Localization in Diseases of the Brain', published in 1875, already appeared in Russia in 1876, followed by editions in Germany and New York only 2 years later in 1878 [6].

Obviously, Kozhevnikov was one of the first of many Russian neurologists to visit Charcot. Moreover, being the head of the department and having a good personal relationship with Charcot, he actually insisted on his young colleagues studying in Paris; he even considered this to be compulsory.

This is exactly what Kozhevnikov advised a 21-yearold S.S. Korsakov (1853-1900) who was appointed as his assistant in 1876. In Paris, Korsakov, due to his interest in psychiatry, was working not only with Charcot, but also with Valentin Magnan (1835-1916), who from 1867 to the end of his career was associated with St. Anne's Psychiatric Clinic in Paris. One of the main fields of interest of Magnan was alcoholism, on which he published several papers in the 1870s [11]. Although there is no direct evidence, it is plausible that the later renowned work of Korsakov on alcoholism: 'About alcoholic paralysis' (1887) and 'Several cases of a particular cerebropathia and polyneuritis' (1889), was influenced by Magnan. Interestingly, Korsakov, just like his teacher, was not impressed by Charcot's work on hysteria and neurosis. Russian psychiatry established itself primarily on somatic and neurological bases. On the whole, French psychiatry, with its succinct logic, clarity of description and concrete clinical approach, seemed to appeal more to the Russian psychiatrists than the German. There was a certain opposition to Kraepelin's nosology in Russia [12]. On return to Moscow, Korsakov became the closest associate of Kozhevnikov and was given full responsibility for the course on mental diseases. Meanwhile, Kozhevnikov proceeded with his conviction that neurology is an independent field of medicine and accordingly encouraged its separa- tion from the mental diseases. Since 1890, there have been two independent departments at the Moscow University Medical Faculty: Nervous Diseases (which was headed by Kozhevnikov) and Mental Diseases (which was headed by Korsakov). This was the historical moment of separation of the two disciplines, whereas in most European countries they would be practiced together for a long time [6].

Needless to say, there was a continual stream of Russian scholars and disciples of Kozhevnikov going to Salpêtrière. This paper will focus on two prominent neurologists: L.O. Minor (1855-1942) and L.O. Darkshevich (1858-1925), who later in their careers, in 1910 and 1919, respectively, served as Chairs of Nervous Diseases in Moscow and founded their own neurological schools.

After graduating from Moscow University, Minor, a student of Kozhevnikov, visited the major European clinics and spent some time at Salpêtrière. He became one of the leading Moscow neurologists and his name is associated with familial essential tremor (tremor multiparus macrobioticus of Minor). Minor was one of the founders and organizers of the Moscow Society of Neurologists and Psychiatrists. During the XIII International Medical Congress in Paris, he was active in lobbying for close international cooperation between neurologists and psychiatrists through the revitalization of the neurological sections on international congresses. From 1910 until 1932, Minor was the head of the Neurological Clinic of the Moscow Institute for Women, later reorganized as the State Moscow Medical Institute, creating his own scientific school with many prominent followers [13].

Another disciple of Kozhevnikov was Darkshevich, best known for the nucleus and fibers that bear his name. After defending his thesis 'The conduction of light stimulus from the retina to the oculomotor nucleus' under Kozhevnikov in Moscow, he took a postgraduate course in Vienna, Leipzig, Berlin and Paris from 1883 to 1887. At Salpêtrière he collaborated with Joseph Jules Dejerine (1839-1917) and co-authored a paper on muscle disorders in tabes dorsalis [14]. Amazingly, the insight into Darkshevich's stay in Paris can be gained from none other than Sigmund Freud (1856-1939). The two of them first met in Vienna in 1884, when Darkshevich translated Freud's paper on the gold chloride method of staining nerve tissue into Russian. In the letters to his future wife from Paris, Freud referred to Darkshevich as 'my friend in cerebro from Moscow' and described not only their work at Salpêtrière, but also the time spent together enjoying the music of Figaro and attending a performance by Sarah Bernhardt [15]. Their friendship and collaboration resulted in the joint publication entitled 'On the Rela- 
tion of the Restiform Body to the Posterior Column and Its Nucleus, with Some Remarks on Two Fields of the Medulla Oblongata' [16]. Upon his return to Russia, Darkshevich became the head of the Department of Nervous Diseases of Kazan Imperial University and actually founded the prominent Kazan School of Neurologists. Later he moved to Moscow and participated in the founding of the State Superior Moscow School (1919). His main scientific approaches were the ones he learned from Charcot at Salpêtrière: the anatomoclinical and morphologicoclinical approaches [14].

It goes without saying that the number of students from St. Petersburg training in Paris was no less than that from Moscow. I.P. Merzheevskii (1838-1908) was one of the first St. Petersburg psychiatrists to be trained in Paris, where he spent 4 years (1872-1875). Being interested both in neurology and psychiatry, in Paris he worked not only with Charcot but also with Magnan. He presented two reports in collaboration with Magnan at the Paris Anthropological Society: one about microcephaly and the other on a change in the brain ventricles in progressive paralysis (1872). In 1874, Merzheevskii independently described the giant pyramidal cells which later became known as the cells of Betz, also a Russian neurologist from Kiev [12]. Merzheevskii is rightly called the 'father and dean of Russian psychiatry'. His clinic in St. Petersburg became a major center for postgraduate training in psychiatry and neurology, with more than two dozen students [17].

The most outstanding student of Merzheevskii, and who would later become the occupant of his chair, was V.M. Bekhterev (1857-1927). After Bekhterev defended his thesis, Merzheevskii recommended him for further studies abroad. His training started in Leipzig under Flechsig and Ludwig, where he mostly worked on anatomomorphological subjects. In 1883, Bekhterev arrived in Paris, where he was greeted by Charcot as an old friend, as they had met during Charcot's visit to St. Petersburg in 1881. Charcot became interested in Bekhterev's morphological material prepared during his work under Flechsig in Leipzig. He was impressed by the erudition and enthusiasm of the young Russian. When he was in Paris, Bekhterev also worked together with Pierre Janet (1859-1947). These two French scholars left their mark on all of Bekhterev's subsequent scientific activities $[12,18]$.

Unlike his Moscow colleagues, Bekhterev became very interested in hypnosis and spent many hours together with Charcot during the hypnotic sessions of patients with hysteria. This very fact would leave its imprint on the differences between the Moscow and St. Petersburg schools of neurology and psychiatry for many years to come. While Kozhevnikov in Moscow had successfully sought the separation of the two disciplines, Bekhterev created a multidisciplinary approach, where he sought to combine neurology, neurophysiology, psychiatry, psychology and neurosurgery. He succeeded in implementing this approach by founding the Psychoneurological Institute in St. Petersburg in 1907, where he remained as Director until his unexpected death in 1927. Along with the fundamental works on anatomy (1894-1896) and physiology of the brain (1903-1907), Bekhterev also published numerous papers on hypnosis, i.e. 'Hypnosis, Suggestion, and Hypnotherapy and Their Therapeutic Significance' (1911). Throughout his life, Bekhterev remained Charcot's admirer; he quoted Charcot's works repeatedly, dedicated three papers to Charcot referring to him as the 'creator of modern neurology', and referred to Salpêtrière as the 'Mecca for all neurologists', the '...place where the real science was taking place' [19-21].

It is interesting to mention that Charcot was open to the ideas from abroad, including Russia. A rather unfortunate example is the suspension apparatus developed in Odessa by A. Motchoukowsky for the traction of the spinal cord and nerves in patients with neurological diseases. The method was introduced in France in 1888 by Raymond. Needless to say, the results were not encouraging, and for the patients it was a very unpleasant experience, which was described by Alphonse Daudet who also underwent this treatment $[2,22]$.

\section{Patients}

Charcot is well known for his broad clientele and his fame as a doctor was not restricted to Paris or France. A huge number of patients from abroad sought help at Charcot's private outpatient clinic or Salpêtrière. The Russians dominated among the foreign patients. There may be many reasons for this, although two explanations would seem fairly evident. Firstly, Paris was traditionally chosen by the Russian aristocracy as a second home and they used to live there in considerable numbers. Secondly, the time of Charcot's medical practice coincided with the mass migration of Russian Jews to the West (1881) due to pogroms resulting from the anti-Semitic policies of the Russian government. Charcot's earliest reference to a male patient with hysteria was a 13 -year-old Russian Jewish boy who presented at his outpatient clinic in 1882 . His famous patients included Grand Duke Nicolas and Grand Duke Constantine of Russia. Count Nicholas Ignatieff, 
the Tsar's Minister of the Interior, sent his 20-year-old son Paul, a future minister, to Paris to consult and be treated by Charcot for nervous exhaustion in 1889-1890 [2].

Many Russian intellectuals and artists were also living in Paris at that time. Prominent among these was a famous Russian writer, I.S. Turgenev (1818-1883), whose novel Fathers and Sons is regarded as one of the major works of 19th century fiction. Turgenev and Charcot knew each other; Turgenev attended Charcot's public lecture demonstrations of hysteria, and they had met during theatrical readings in Alphonse Daudet's house. When Turgenev became ill, he consulted Charcot (April 5, 1882), who wrongly diagnosed angina pectoris. Turgenev died after a long delirium due to cancer of the spinal cord. It has to be said, though, that another great Russian writer, L.N. Tolstoy (1828-1910), was far from being a Charcot admirer. Charcot is the only physician cited by name and called an arrogant 'priest of science' in his novel The Kreutzer Sonata (1887-1889). In Tolstoy's personal diary (1889), one can find the following entry: 'Paris with Eiffel Tower, prostitution, Charcot, etc'. Nevertheless, when Tolstoy's son Lev became ill in 1899, the family consulted Édouard Brissaud (1852-1909), who was taught by Char$\cot [23]$.

It is noteworthy that Charcot's very last patient was a Russian lady. He made a house call to her in August 1893. She was a patient of A. Lubimoff, a Russian disciple of Charcot and his friend for 20 years. He spent the winter season in Nice, treating Russian emigrants from the end of 1880, and finally settled in France. Lubimoff was Charcot's first biographer.

\section{Visits to Russia}

From the accounts presented in this paper, it is obvious that Charcot had many contacts with Russia through his patients and colleagues. His fame spread beyond the French border. His first visit to Russia was in 1881, and he visited both capitals - Moscow and St. Petersburg. The actual reason was to treat the daughter of a former mayor of Moscow. One report (Le Temps, March 18, 1881) from the French press covering Charcot's visit stated, 'The illustrious practitioner was covered with rhetorical flourishes and deafened by the applause that followed his route. There are few foreign doctors as popular in Russia as M. Charcot; his Russian clientele in Paris is very numerous.' Another account (Gazette hebdomodaire de médecine, April 15, 1881) reported, 'At Petersburg, on the express in- vitation of physicians, Charcot received patients from eight in the morning until noon. At Moscow the number of those who came for consultation made it necessary to refuse those not accompanied by their doctors... Charcot goes to the private hospital of professor Botkin (in Moscow) who gave at that moment his lecture. Mr Botkin comes courteously to him; the pupils, numbering four or five hundred, get up all and applaud; applauses redouble when the professor asks his public for the permission to continue his lecture in French.' There were also reports of the lavish St. Petersburg banquet with 'an incredible number of toasts', mostly to solidarity between French and Russian medical science [2]. One of Charcot's many gifts was his ability to draw patients and depict essential features of illnesses. Among Charcot's numerous medical drawings now kept at the Bibliothèque Charcot at Salpêtrière are the sketches he made during his trip to Russia (fig. 1).

His second visit in 1891 was Charcot's last major trip. This time he was called to Russia by Grand Duke Constantine. In those days, the journey from Paris to Moscow required 3 days. Charcot was accompanied by his daughter, Jeanne, and son, Jean. He visited patients and they came to consult him; he even travelled in the country for extra consultations. It would have been strange to be in Moscow and not visit the brand new clinic for nervous diseases where many of his ex-pupils worked, headed by Kozhevnikov. On the photo made on this occasion, one can see them all posing in front of the clinic building (fig. 2) [6]. In Moscow, the Charcots were hosted by Poliakoff, the major railway magnate. On July 14, as the family departed in Poliakoff's private train, Jeanne was surrounded by bouquets of flowers in the French colors [2].

\section{In Memoriam}

Charcot's death on August 16, 1893, led to a proliferation of obituaries, the longest of which (72 pages) was by a Russian disciple and friend, A.A. Lubimoff (1894): Le Professeur Charcot [24]. It is symbolic that the representatives of both the Moscow and St. Petersburg schools responded to this sad event. In Moscow, on October 24, 1893, at a special session of the Moscow Society of Neurologists and Psychiatrists, Minor gave a presentation 'Life and work of Professor Charcot', which was later published [25]. In St. Petersburg, Bekhterev published 'In memoriam' in the Neurological Herald [19]. 


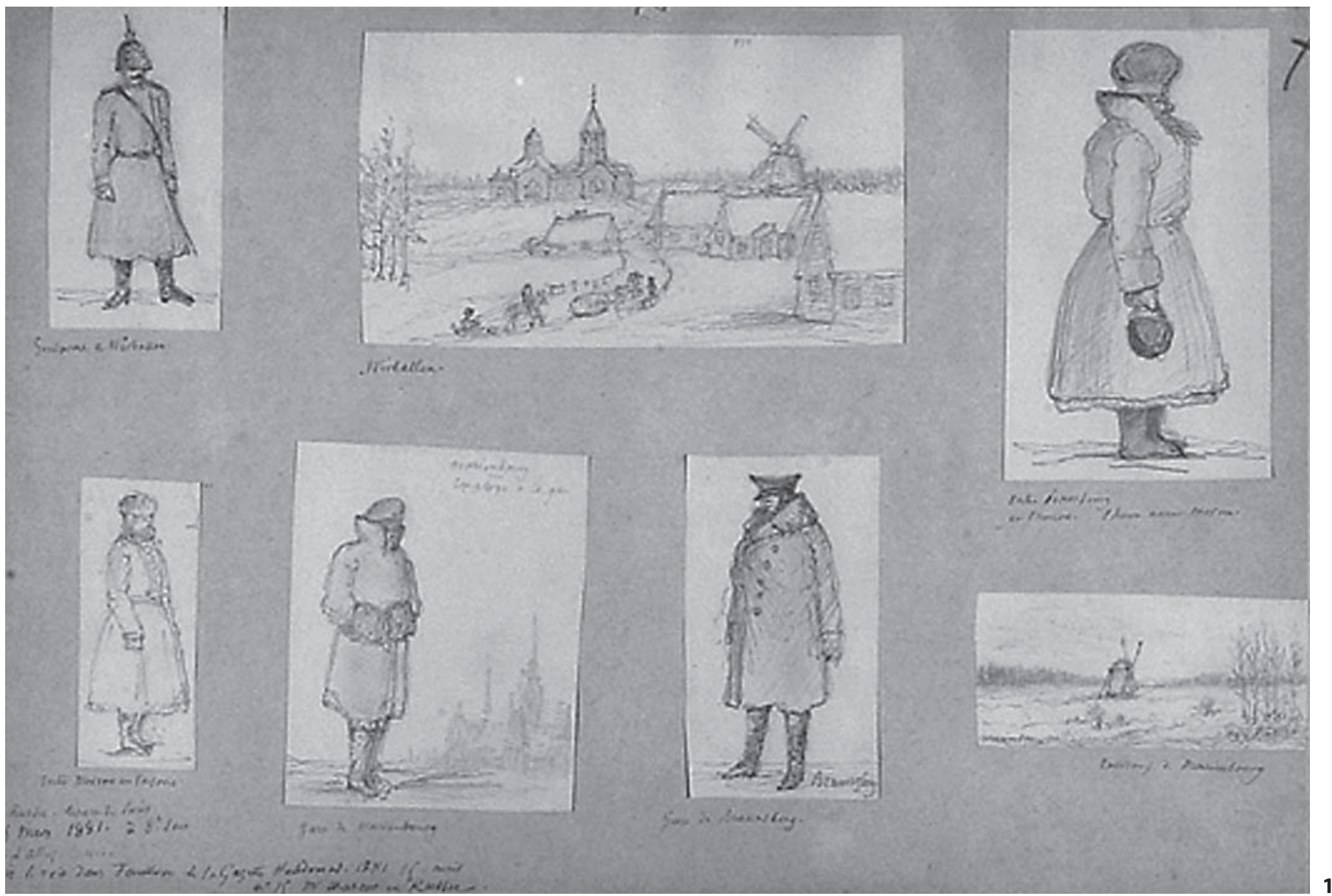

Fig. 1. Charcot's drawings made during his visit to Russia in 1881. Courtesy of Bibliothèque Charcot (UPMC-Université Pierre et Marie Curie) - Hôpital de la Salpêtrière. Fig. 2. J.-M. Charcot and Moscow neurologists in 1891. J.-M. Charcot and his daughter Jeanne sitting in the center, and A.Ya. Kozhevnikov sitting on the right. Standing (from left to right): V.A. Muratov, G.I. Rossolimo, Jean (son of Charcot), G.I. Pribytkov, V.K. Rot, L.S. Minor.

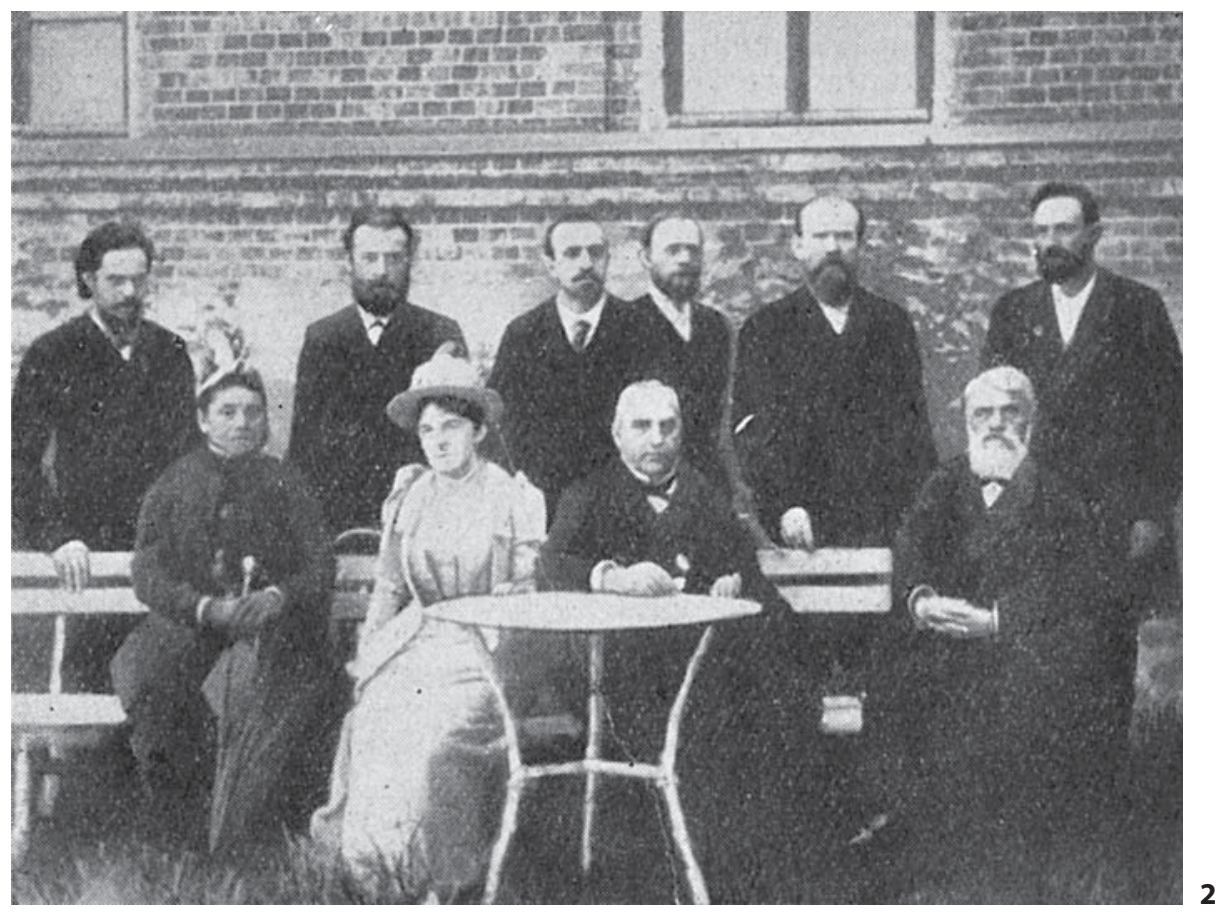




\section{Conclusion}

Russian neurology was actually nonexistent in the middle of the 19th century, which made a traineeship abroad an absolute necessity. Charcot and his school did not just offer professional training; they created the best minds, which would determine the direction of neurology in Russia for many decades. After returning home, young Russian doctors not only implemented everything they learned in Western Europe, but proceeded to make their own original contributions. There is ample proof of this in the eponymous list of classical neurological symptoms, syndromes and diseases where one comes across names of great Russian scientists: Kozhevnikov epilepsy, Korsakov syndrome, Rossolimo sign, Bekhterev sign, Minor tremor, Betz cells, and many others. The most talented pupils of Charcot became the founders of neurological and psychiatric schools in Russia, which foresaw the future development of the two disciplines. Remarkably, though trained by the same teachers, each individual future 'founding father' of the neurological and psychiatric schools chose his own individual way. This led to an undeniable diversity in Russian neurology and psychiatry during the period of their formation. Russian pupils of Charcot were actually more successful than his closest followers in France. Without his support, his students lost favor to candidates from competing schools. His rising star, Pierre Marie, 39-years-old when Charcot died, had to wait 24 years to occupy his mentor's chair. Others, such as Babinski and Gilles de la Tourette, were relegated to lesser positions, never achieving the rank of professor [2].

In conclusion, we can deduce that Charcot's Russian disciples, though relatively late starters, were quick learners. Using their own original approach, the achievements of these capable students were considerable.

\section{Disclosure Statement}

The author has no conflicts of interest to disclose. I confirm that I have read the Journal's position on issues involved in ethical publication and affirm that this report is consistent with those guidelines.

\section{References}

1 Mackay FH, Legrand E: Jean Martin Charcot 1825-1893. Arch Neurol Psychiatry 1935;34: 390-400.

2 Goetz CG, Bonduelle M, Gelfand T: Charcot. Constructing Neurology. New York, Oxford University Press, 1995.

3 Bogousslavsky J (ed): Following Charcot: A Forgotten History of Neurology and Psychiatry. Front Neurol Neurosci. Basel, Karger, 2011, vol 29.

4 Régnier C: French medicine in Russia. Medographia 2006;28,1:78-87.

5 Zabludovskii PE: S. P. Botkin and the development of clinical medicine in Russia in the 19 th century (on the 100th anniversary of the publication of Course of Study of the Clinical Aspects of Internal Disease, by S. P. Botkin) (in Russian). Klin Med (Mosk) 1968;46: 148-52.

6 Lisitsin YP: Kozhevnikov AYa i moskovskaya shkola nevropatologov (Moscow School of Neuropathology). Moskva, Moskva Medgiz, 1961.

7 Pearce JMS: Amyotrophic lateral sclerosis. J Neurol Neurosurg Psychiatry 2002;73:671.

8 Kozhevnikov AY: Opisanie klinicheskogo zavedeniay dlya umalishennyx Svaytoi Anny v Parige (Report on the St. Anne's psychiatric clinic in Paris). Moskva, Univ. Izvestiay Moskovskogo Universiteta, 1867, No. 11.
-9 Lichterman B. Chapter 45: a history of Russian and Soviet neuro(patho)logy. Handb Clin Neurol. 2010;95:737-754.

10 Kozhevnikov AY: Osobyj vid kortikaljnoj epilepsii. (A Particular Type of Cortical Epilepsy). Medizinskoe obozrenie 1894;14:1921.

11 Ovsyannikov SA, Ovsyannikov AS: SergeyS. Korsakov and the beginning of Russian psychiatry. J Hist Neurosci 2007;16:58-65.

12 Zilboorg G: Russian psychiatry - its historical and ideological background. The bulletin. NY Soc Med Hist 1943;19:713-728.

13 Chodos HBG: Kratkij Ocherk Otechestvennoj Nevrologii (Short review on Soviet Neurology). Irkutsk, Vostochno Sibirskoe Knignoe Izdateljstvo, 1965.

14 Amirov NKh, Bogdanov EI, Guryleva ME, Zefirof AI, Ismagilov MF, Mukhamedzyanov RZ, Sozinov AS: The history of Kazan neurological school. J Hist Neurosci 2007;16: 110-122.

15 Golden RL: Gertrude Stein (1874-1946) and the nucleus of Darschewitch: a discursive commentary. J Med Biogr 2009;17:55-60.

16 Darkschewitsch L, Freud S: Ueber die Beziehung des Strickkoerpers zum Hinterstrang und Hinterstrangkern nebst Bemerkungen ueber zwei Felder der Oblongata. Neurol Zbl 1886;5:121-129.
17 Sirotkina I: Diagnosing Literary Genius: A Cultural History of Psychiatry in Russia, 1880-1930. Baltimore, Johns Hopkins University Press, 2002.

18 Skoromets AA, Akimenko MA, Djakonov $\mathrm{MM}$, et al: Influence of European neurology on young Bekhterev (in Russian). Neurol Herald 2007;29; 1:164-167.

19 Bekhterev VM: In memoriam (in Russian). Neurol Herald 1893;1:3.

20 Bekhterev VM: Memoires about Charcot (in Russian). Mod Psychoneurol 1925;8.

21 Bekhterev VM: Memoires about Charcot (in Russian). Knowl Bull 1926;12.

22 The Suspension Treatment. J Am Med Assoc, 1890;14:21-22.

23 Porudominsky VI: Lev Tolstoy v prostranstve medicini. [Leo Tolstoy in the space of medicine] (in Russian). Moskva, Eidos Media, 2004

24 Lubimoff AA: Professor Charcot. ScientificBiographical Sketch (in Russian). St. Petersburg, Suvorin, 1894.

25 Minor LS: Life and work of Professor Charcot, speech delivered by docent of Moscow University Minor, 24 October 1893 (in Russian). Moscow, Kumnarev \& Co, 1894 